\title{
HIV 感染病態におけるケモカインの役割
}

\author{
義 江修
}

Jpn. J. Clin. Immun., 23 (6) : 591 591, 2000.

HIV は無症候期でおもに2 次リンパ組織で潜伏・ 持続感染している. 2 次リンパ組織では抗体や補体と 結合したウイルス粒子が Fcレセプターや補体レセプ ターを介して滤胞樹状細胞にトラップされて比較的安 定に存在し, 再循環過程で樹状細胞に次々と接触して くるナイーブT細胞に伝播していくと考えられてい る. 一方 HIV 感染 T 細胞の方はおもにリンパ組織に とどまり，多くが潜伏感染状態で，一部がサイトカイ ンや抗原刺激などにより活性化されてウイルスの産生 を行うと考えられている. そのため HIV の潜伏・持 続感染は 2 次リンパ組織の微小環境に存在するさまざ まな宿主因子の影響下にあると考えられる，2次リン パ組織における HIV の潜伏・持続感染のメカニズム を明らかにし，それに対する有効な治療法を開発する ためには，まずその分子メカニズムを明らかにしなけ ればならない.我々は 2 次リンパ組織での HIV の潜
伏・持続感染に影響を与える宿主因子として，2 次リ ンパ組織で発現する種々のケモカインに注目して解析 を行っている。例えば, CCケモカインSLC と ELC は 2 次りンパ組織で構成的に発現し, 共有レセプター である CCR 7 はリンパ球や樹状細胞という HIV の標 的細胞に広範に発現しているため, HIV の潜伏・持 続感染に直接的あるいは間接的に影響する可能性があ る.そして我々は SLC と ELCがX 4 およびR 5 夕 イプの HIV-1 の活性化 PBMCでの增殖を促進する ことを見い出した.この効果は百日咳毒素で阻止さ れ，CCR 7 を介して行われると考えられる。同様の 効果は感染をブロックしない状況では SDF-1や RANTESでも報告されて抢り，ケモカインレセプタ 一からのシグナル伝達の共通の効果のひとつと考えら れる. 現在, HIV の増殖を促進するケモカインレセ プターからのシグナル伝達について解析中である. 